Volume 10, No.5, September - October 2021

International Journal of Advanced Trends in Computer Science and Engineering

Available Online at http://www.warse.org/IJATCSE/static/pdf/file/ijatcse171052021.pdf

https://doi.org/10.30534/ijatcse/2021/171052021

\title{
Mandarin Language Learning with Gamification Method
}

\author{
Fedro $^{1}$, Wirawan Istiono ${ }^{2}$ \\ ${ }^{1}$ Universitas Multimedia Nusantara, Indonesia, fedro@ student.umn.ac.id \\ ${ }^{2}$ Universitas Multimedia Nusantara, Indonesia,wirawan.istiono@umn.ac.id
}

Received Date : August 08, 2021 Accepted Date : September 16, 2021 Published Date : October 06, 2021

\begin{abstract}
The rapid economic and industrial development in China over the past few decades has made Mandarin more in demand as a business and cultural language, and now Mandarin is the second most popular international language. Therefore, learning Mandarin is something that is quite important in this era of globalization. However, to learn Mandarin is not an easy thing because Mandarin is a language that is quite difficult to master. So that it can reduce motivation to continue learning and in the end decide to stop learning Mandarin. Based on these problems, in this study, we will design and develop a mandarin learning application with the gamification method using the Octalysis framework to increase motivation in learning Mandarin. and will measure the level of behavioral intention to use and user immersion towards the application using the Hedonic Motivation System Adoption Model (HMSAM). The tests have been conducted and prove that gamification can increase the user's motivation to continue learning Mandarin. This is shown based on the evaluation conducted, the user states strongly agrees that the application that has been designed and built can improve the behavioral aspect of intention to use, this is indicated by the percentage value obtained by $82.47 \%$. And agree that the application can cause immersion aspects when using the application, this is indicated by the percentage value obtained by $79.56 \%$.
\end{abstract}

Key words: Behavioral intention to use, gamification, HMSAM, immersion, Mandarin, Octalysis.

\section{INTRODUCTION}

Humans are social creatures who cannot live alone and always need other people to continue their lives. It is undeniable that everyday humans always depend on other people. In social life, humans need to interact with each other to make a social relationship. While social relations can be created by communication. Communication that occurs between social beings in the form of language. Language is a means of communication to convey a message so that the communication process occurs. Mastery of both speaking and writing helps in smooth communication [1]. Mandarin is one of the languages with the largest number of native speakers in the world. The rapid development of economy and industry in China over the past few decades has made Mandarin increasingly in demand as a business and cultural language. This fact makes mandarin as the second most popular international language [2]. Therefore, learning mandarin is very important. In the era of globalization, because people will not only meet people from around the world who speak English only. But will also meet people from china who speak mandarin, because the Chinese population is $20 \%$ of the world's population [1].

The development of technology is very influential on the way of learning, especially in the use of learning media. Currently most people are already fluent in using smartphone technology [3]. This has also influenced the study habits in society. Therefore, it is necessary to optimizing the use of smartphone in learning [4]. Gamification is a learning strategy that motivate user to solve a problem through the way of thinking when playing games [5]-[7]. There are several positive things related to the application of gamification in learning, the learning process becomes more interactive and efficient, make user more enthusiastic and motivated in learning, learning become more fun without forgetting the existing material so that create a balance between learning and play, and the user becomes more active in participating in learning [8]-[10]. As in states that mandarin language education has been carried out by many educational institutions, including higher education institutions. However, there are still many who experience a decline in grades until they stop learning because they feel that mandarin is difficult to learn. Whereas one of the factors that affect learning achievement is the factor of learning motivation [11]

As in which conducted on m-learning based mandarin learning. Getting a positive response and significantly becoming more interesting and at the same time an alternative media for interactive learning of mandarin that can increase interest in learning [12], rather than using 
Fedro et al., International Journal of Advanced Trends in Computer Science and Engineering, 10(5), September - October 2021,3046 - 3052

ordinary learning media. There is also, studies concerning the application of the framework Octalysis gamification to the conclusion that gamification elements managed to increase the interest [13], motivation, understanding of materials, and can be a good alternative learning media. Based on the background and references of previous research, this study aims to design and build a mandarin learning application with the gamification method using the Octalysis framework which is considered to increase interest and motivation in learning. And see how much motivation and interest user have, by measuring the Behavioral Intention to Use (BIU) in using application and immersion in the application usng the Hedonic Motivation System Adoption Model (HMSAM) [14].

\section{RESEARCH METHOD}

Mandarin is one of the six languages spoken in the United Nations, and has the largest number of native speakers in the world. In mandarin, the thing that is learned is not only the translation, but is expected to be able to memorize how to read, write, and Chinese characters (hanzi). Here are the important aspects of mandarin [15]:

1. Pinyin

Pinyin is a latin way of reading chinese characters.

2. Shengdiao

In mandarin, required to be able to memorize vocabulary and its tone correctly. If pronounce the tone wrong, it will have a different meaning.

3. Hanzi

Hanzi is a letter that comes directly from China. A type of logogram used to write chinese languages.

Gamification is a learning approach using elements in video games with the aim of motivating user in the learning process and maximizing feelings of enjoyment and involvement in the learning [7], [8].

Octalysis is a human-centeric gamification design framework developed by Yu-kai Chou. Chou concluded that there are eight types of core drives that motivate a person to perform certain activities. Core drives push people in different directions and not everyone is motivated by the same drives [13].

Hedonic Motivation System Adoption Model is a model to measure a system that adapts hedonic motivation. There are seven factors that are the focus of measurement in HMSAM [14]:

1. Perceived usefulness, measuring performance improvement when using a system.

2. Perceived ease of use, measuring the ease of use of a system.

3. Curiosity, measuring the extent to which a system can increase curiosity in cognitive aspects.
4. Control, measuring user perceptions in interacting with the system.

5. Joy, measuring the pleasure obtained from interaction with the system.

6. Behavioral intention to use, measuring the desire to use the application.

Focused immersion, measuring how deeply the user is focused in using the system

Likert scale is a scale used to measure attitudes, opinions, and perceptions of a person or group of people about social phenomena [16]. In the measurement, calculations will be made using a formula for statements that include positive statements (not starred) using the formula:

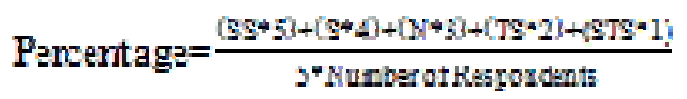

As for the statement that included a negative statement (star *) using the formula:

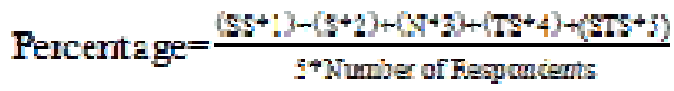

The literature review stage is useful to support the topics brought in the research. At this phase, the theories that will support the research topic are described. And the analysis step is useful for determining the things that are needed in the research based on the literature review used, and analyzing the mandarin language learning material. Next phase is application design that useful for designing gamification, application models, flowchart, mockups, and required assets. And the application implementation phase using Integrated Development Environment (IDE) Android Studio using the JAVA programming language and using firebase for the database. After that, application testing phase is useful for testing applications that have been completed. After testing the user will be asked to fill out a questionnaire that has been provided, and the final phase is the evaluation phase of the application test results is useful for processing the data obtained from the application test results. Then an evaluation will be carried out using a likert scale to measure the success rate of the application.

\section{METHOD}

The mandarin learning application with the android-based gamification method is implemented based on a mockup design that has been made at the design stage. In Figure 1 shows the first gameplay menus 


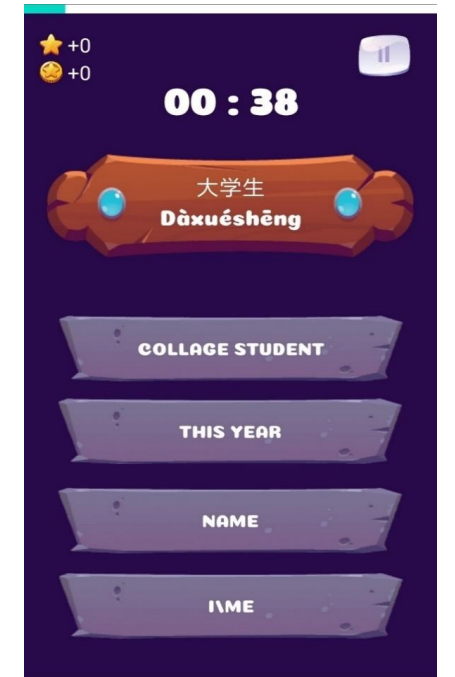

Figure 1: Quiz Game Implementation

Figure 1 shows the result of the implementation of the quiz game, In this menus will show progress bar, total experience and coins that have been obtained will be displayed, pause button, countdown, question, and four answers choices. Every time the game is start, the sequence of questions in the game will always be randomized and the position of the answer will also be randomized. The progress bar will indicate the number of questions that have been completed by the user. Experience point and the coins indicate the total experience and coins that have been earned during the game. The pause button serves to display a dialogue containing the stage, resume, and restart, this button can be pressed as long as the game is still ongoing. On the answer button, each user chooses an answer, checking whether the answer is right or wrong. If the correct answer is selected, the button will turn green, while if the wrong button is selected, it will turn red and show the button with the correct answer.

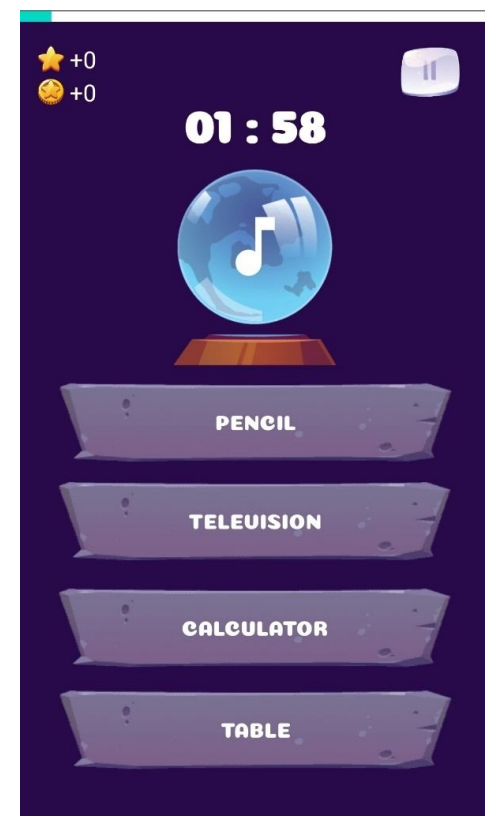

Figure 2. Implementation Quiz Game with Sound
Figure 2 shows the result of the quiz menus game. In this quiz games menu provides answer choices and also has voice assistance, unlike the previous quiz where the quiz questions are in the form of writing, in this menu section, the form will be changed into a button that can be pressed and then the user will hear question voice in mandarin language.

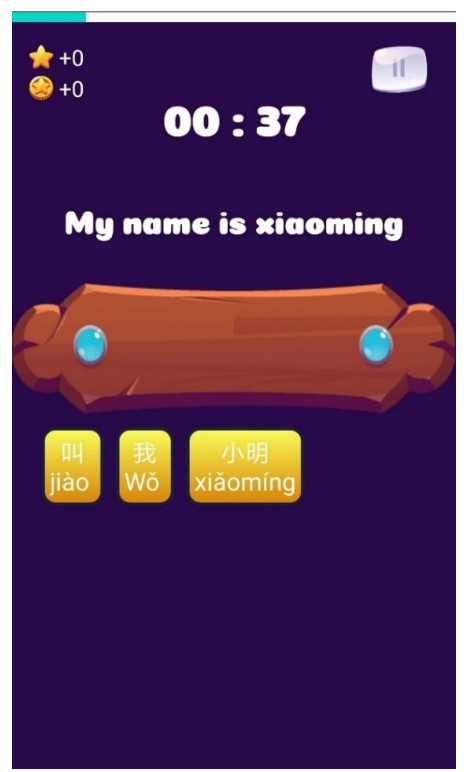

Figure 3. Implementation Word Arranging Game

Figure 3 shows the result of the implementation of the word stacking game, different from the two previous gameplay, in this section the user must arrange words in Mandarin into a correct sentence according to the questions given. If the answer given is wrong, the text will turn red, while if it is correct, the text will turn green.

\section{RESUlt AND ANALYSIS}

Application testing is carried out by field testing by distributing the application download link, along with questionnaire link to user. The questionnaire was created using the HMSAM model to measure the level of behavioral intention to use and immersion of users toward the application. From the test carried out, there were 35 respondents who had filled out the questionnaire. The following is a list of questions given to respondents using the HMSAM model.

Table 1: Attributes of Cleveland dataset

\begin{tabular}{|l|}
\hline \multicolumn{1}{|c|}{ Questions } \\
\hline Perceived ease of use \\
1. I can interact with the application very clearly \\
and easy to understand. \\
2. I feel that the user interface displayed is very easy \\
to understand and does not make me confused. \\
3. I can easily buy/use avatars, change names, and \\
\hline
\end{tabular}


Fedro et al., International Journal of Advanced Trends in Computer Science and Engineering, 10(5), September - October 2021 , 3046 - 3052

\section{play games.}

4. I can use the application without any problem

5. I find it difficult to learn how to use application.

6. I find the application easy to use

\section{Perceived usefulness}

1.The application made me understand about mandarin

2. The application gave me knowledge.

3. The application helps me pass my free time more usefully.

4. I did not get anything from the application.

5. The application makes me more motivated to learn mandarin.

\section{Curiosity}

1. The application makes me curious

2. I feel more curious when using the application

3. I wonder if I can unlock all stages in application

4. I am curious to get all the achievements in application

5. I wonder if I can occupy the top spot on the leaderboard

6. I can't wait to buy and use the new avatar

\section{Control}

1. I have a lot of control over application

2. I can choose freely what I want to do

3. I have no control over my interactions.

4. I am in control of my interactions

Joy

1. I enjoy using the application

2. The application provides fun learning.

3. The application makes me feel bored.

4. I am satisfied with the application

5. The application makes me feel annoyed.

Behavioral Intention to Use

1. I will use the application again.

2. I will continue to use the application.

3. I hope to continue using the application in the future

Immersion

1. I can use the application regardless of anything

\section{else}

2. I feel immersed in the use of the application

3. I can't take my focus off the application

4. I can easily get distracted by other things when using the application

Table 1 shows a list of questions on the questionnaire which consists of 33 questions which are divided into seven parts, namely, perceived ease of use, perceived usefulness, curiosity, control, pleasure. (joy), reuse (behavioral intention to use), carried away (immersion).

Table 2: Perceived ease of use table

\begin{tabular}{|c|l|l|}
\hline No. & Calculation & Result \\
\hline 1 & $\begin{array}{l}(((2 * 1)+(1 * 2)+(2 * 3)+(16 * 4)+(14 * 5)) \\
/(5 * 35)) * 100 \%\end{array}$ & $\begin{array}{l}82,28 \\
\%\end{array}$ \\
\hline 2 & $\begin{array}{l}(((1 * 1)+(2 * 2)+(2 * 3)+(12 * 4)+(18 * 5)) \\
/(5 * 35)) * 100 \%\end{array}$ & $\begin{array}{l}85,14 \\
\%\end{array}$ \\
\hline 3 & $\begin{array}{l}(((0 * 1)+(3 * 2)+(0 * 3)+(16 * 4)+(16 * 5)) \\
/(5 * 35)) * 100 \%\end{array}$ & $\begin{array}{l}85,71 \\
\%\end{array}$ \\
\hline 4 & $\begin{array}{l}(((1 * 1)+(2 * 2)+(4 * 3)+(7 * 4)+(21 * 5)) / \\
(5 * 35)) * 100 \%\end{array}$ & $\begin{array}{l}85,71 \\
\%\end{array}$ \\
\hline 5 & $\begin{array}{l}(((18 * 5)+(6 * 4)+(5 * 3)+(4 * 2)+(2 * 1)) / \\
(5 * 35)) * 100 \%\end{array}$ & $\begin{array}{l}79,42 \\
\%\end{array}$ \\
\hline 6 & $\begin{array}{l}(((2 * 1)+(1 * 2)+(1 * 3)+(12 * 4)+(19 * 5)) \\
/(5 * 35)) * 100 \%\end{array}$ & $\begin{array}{l}85,71 \\
\%\end{array}$ \\
\hline
\end{tabular}

Table 2 shows the results of measurements of the perceived ease of use. From the result that shown in Table2, the average value can be obtained is $83.99 \%$, so it can be concluded that the respondents strongly agree that the application of learning Mandarin with the gamification method is felt to be very easy to use.

Table 3: Perceived usefulness table

\begin{tabular}{|c|l|c|}
\hline No. & \multicolumn{1}{|c|}{ Calculation } & Result \\
\hline 1 & $\begin{array}{l}(((1 * 1)+(3 * 2)+(3 * 3)+(10 * 4)+(18 * 5)) / \\
(5 * 35)) * 100 \%\end{array}$ & $83,42 \%$ \\
\hline 2 & $\begin{array}{l}(((1 * 1)+(3 * 2)+(0 * 3)+(15 * 4)+(16 * 5)) / \\
(5 * 35)) * 100 \%\end{array}$ & $84 \%$ \\
\hline 3 & $\begin{array}{l}(((0 * 1)+(3 * 2)+(6 * 3)+(7 * 4)+(19 * 5)) / \\
(5 * 35)) * 100 \%\end{array}$ \\
\hline 4 & $\begin{array}{l}(((19 * 5)+(8 * 4)+(2 * 3)+(5 * 2)+(1 * 1)) / \\
(5 * 35)) * 100 \%\end{array}$ & $82,28 \%$ \\
\hline 5 & $\begin{array}{l}(((0 * 1)+(4 * 2)+(1 * 3)+(12 * 4)+(18 * 5)) / \\
(5 * 35)) * 100 \%\end{array}$ & $85,14 \%$ \\
\hline
\end{tabular}

Table 3 shows the results of the measurement of the perceived usefulness aspect. Based on the results obtained in table 3, the average value can be obtained is $83.76 \%$, so it can be concluded that the respondents strongly agree that the application of learning Mandarin with the gamification method is considered very useful. 
Table 4: Curiosity table

\begin{tabular}{|l|l|l|}
\hline No. & Calculation & Result \\
\hline 1 & $\begin{array}{l}(((1 * 1)+(2 * 2)+(3 * 3)+(18 * 4)+(11 * 5) \\
) /(5 * 35)) * 100 \%\end{array}$ & $\begin{array}{l}80,57 \\
\%\end{array}$ \\
\hline 2 & $\begin{array}{l}(((0 * 1)+(3 * 2)+(3 * 3)+(8 * 4)+(21 * 5)) \\
/(5 * 35)) * 100 \%\end{array}$ & $\begin{array}{l}80,85 \\
\%\end{array}$ \\
\hline 3 & $\begin{array}{l}(((2 * 1)+(1 * 2)+(5 * 3)+(17 * 4)+(10 * 5) \\
) /(5 * 35)) * 100 \%\end{array}$ & $\begin{array}{l}78,28 \\
\%\end{array}$ \\
\hline 4 & $\begin{array}{l}(((1 * 1)+(3 * 2)+(7 * 3)+(12 * 4)+(12 * 5) \\
) /(5 * 35)) * 100 \%\end{array}$ & $\begin{array}{l}77,71 \\
\%\end{array}$ \\
\hline 5 & $\begin{array}{l}(((2 * 1)+(1 * 2)+(4 * 3)+(7 * 4)+(21 * 5)) \\
/(5 * 35)) * 100 \%\end{array}$ & $\begin{array}{l}84,14 \\
\%\end{array}$ \\
\hline 6 & $\begin{array}{l}(((1 * 1)+(3 * 2)+(3 * 3)+(13 * 4)+(15 * 5) \\
) /(5 * 35)) * 100 \%\end{array}$ & $\begin{array}{l}81,71 \\
\%\end{array}$ \\
\hline
\end{tabular}

Table 4 shows the results of measurements of the Curiosity aspect. Based on the results obtained in table 4, the average value can be obtained is $80.54 \%$, so it can be concluded that the respondents strongly agree that the application of learning Mandarin with this gamification method can create curiosity for users.

Table 5. Control table

\begin{tabular}{|c|l|c|}
\hline No. & \multicolumn{1}{|c|}{ Calculation } & Result \\
\hline \multirow{2}{*}{1} & $(((1 * 1)+(0 * 2)+(1 * 3)+(11 * 4)+(20 * 5)$ & 84,57 \\
& )$/(5 * 35)) * 100 \%$ & $\%$ \\
\hline \multirow{2}{*}{2} & $(((0 * 1)+(2 * 2)+(3 * 3)+(15 * 4)+(15 * 5)$ & 84,57 \\
& )$/(5 * 35)) * 100 \%$ & $\%$ \\
\hline \multirow{2}{*}{3} & $\begin{array}{l}(((22 * 5)+(7 * 4)+(2 * 3)+(1 * 2)+(3 * 1)) \\
\text { / }(5 * 35)) * 100 \%\end{array}$ & $\begin{array}{c}85,14 \\
\%\end{array}$ \\
\hline \multirow{2}{*}{4} & $\begin{array}{l}(((1 * 1)+(2 * 2)+(0 * 3)+(18 * 4)+(14 * 5) \\
) /(5 * 35)) * 100 \%\end{array}$ & $84 \%$ \\
\hline
\end{tabular}

Table 5 shows the results of measurements of the control aspect (Control). Based on the results obtained in table 5, the average value can be obtained is $84.57 \%$, so it can be concluded that the respondents strongly agree that the application of mandarin learning with this gamification method users can control the interaction in the application freely.

Table 6: Joy table

\begin{tabular}{|c|l|l|}
\hline No. & \multicolumn{1}{|c|}{ Calculation } & Result \\
\hline \multirow{2}{*}{1} & $\begin{array}{l}(((2 * 1)+(1 * 2)+(1 * 3)+(11 * 4)+(20 * 5) \\
) /(5 * 35)) * 100 \%\end{array}$ & $\begin{array}{l}86,28 \\
\%\end{array}$ \\
\hline \multirow{2}{*}{2} & $\begin{array}{l}(((1 * 1)+(2 * 2)+(2 * 3)+(10 * 4)+(20 * 5) \\
) /(5 * 35)) * 100 \%\end{array}$ & $\begin{array}{l}86,28 \\
\%\end{array}$ \\
\hline \multirow{2}{*}{3} & $\begin{array}{l}(((18 * 5)+(8 * 4)+(6 * 3)+(1 * 2)+(2 * 1)) \\
/(5 * 35)) * 100 \%\end{array}$ & $\begin{array}{l}82,28 \\
\%\end{array}$ \\
\hline \multirow{2}{*}{4} & $\begin{array}{l}(((0 * 1)+(1 * 2)+(1 * 3)+(17 * 4)+(16 * 5) \\
) /(5 * 35)) * 100 \%\end{array}$ & $\begin{array}{l}87,42 \\
\%\end{array}$ \\
\hline \multirow{2}{*}{5} & $\begin{array}{l}(((21 * 5)+(6 * 4)+(3 * 3)+(2 * 2)+(3 * 1)) \\
/(5 * 35)) * 100 \%\end{array}$ & $\begin{array}{l}82,85 \\
\%\end{array}$ \\
\hline
\end{tabular}

Table 6 shows the results of measurements of the pleasure aspect (Joy). Based on the results obtained in Table 6, the average value can be obtained is $85.02 \%$, so it can be concluded that the respondents strongly agree that the application of learning Mandarin with this gamification method can provide pleasure to users.

Table 7: Behavioral intention to use table

\begin{tabular}{|c|l|l|}
\hline No. & Calculation & Result \\
\hline \multirow{2}{*}{1} & $(((1 * 1)+(2 * 2)+(2 * 3)+(8 * 4)+(22 * 5))$ & $\begin{array}{l}87,42 \\
\%\end{array}$ \\
\hline \multirow{2}{*}{2} & $/(5 * 35)) * 100 \%$ & $((1 * 1)+(3 * 2)+(2 * 3)+(23 * 4)+(6 * 5))$ \\
& $/(5 * 35)) * 100 \%$ & $\begin{array}{l}77,14 \\
\%\end{array}$ \\
\hline \multirow{2}{*}{3} & $(((2 * 1)+(2 * 2)+(1 * 3)+(14 * 4)+(16 * 5)$ & $\begin{array}{l}82,85 \\
\%\end{array}$ \\
\hline
\end{tabular}

Table 7 shows the results of the measurement on the aspect of reuse (Behavioral Intention to Use). Based on the results can be obtained in table 7 , the average value obtained is $82.47 \%$, so it can be concluded that the respondents strongly agree that the application of learning Mandarin with this gamification method can make users to reuse the application in the future.

Table 8: Immersion table

\begin{tabular}{|c|l|l|}
\hline No. & Calculation & Result \\
\hline 1 & $\begin{array}{l}(((3 * 1)+(1 * 2)+(3 * 3)+(15 * 4)+(13 * 5) \\
) /(5 * 35)) * 100 \%\end{array}$ & $\begin{array}{l}79,42 \\
\%\end{array}$ \\
\hline 2 & $\begin{array}{l}(((4 * 1)+(0 * 2)+(1 * 3)+(15 * 4)+(15 * 5) \\
) /(5 * 35)) * 100 \%\end{array}$ & $\begin{array}{l}81,14 \\
\%\end{array}$ \\
\hline 3 & $\begin{array}{l}(((2 * 1)+(3 * 2)+(2 * 3)+(15 * 4)+(13 * 5) \\
) /(5 * 35)) * 100 \%\end{array}$ & $\begin{array}{l}79,42 \\
\%\end{array}$ \\
\hline 4 & $\begin{array}{l}(((16 * 5)+(9 * 4)+(5 * 3)+(1 * 2)+(4 * 1)) \\
/(5 * 35)) * 100 \%\end{array}$ & $\begin{array}{l}78,28 \\
\%\end{array}$ \\
\hline
\end{tabular}

Table 8 shows the measurement results on the immersion aspect. Based on the results obtained in Table 8, the average value can be obtained is $79.56 \%$, so it can be concluded that respondents agree that the application of learning Mandarin with this gamification method can make users get carried away when using the application.

Based on the calculation in Table 2, Table 3, Table 4, Table 5, Table 6, Table 7, Table 8 , the value of each question according to category has been obtained. From this value, the average value of each variable has been obtained. The average value for these variables can be seen in Table 9 .

Table 9. Table of Average Value of Each Variable

\begin{tabular}{|c|l|l|}
\hline No. & Category & Result \\
\hline 1 & Perceived ease of use & $\begin{array}{l}83,99 \\
\%\end{array}$ \\
\hline 2 & Perceived usefulness & $\begin{array}{l}83,76 \\
\%\end{array}$ \\
\hline 3 & Curiosity & $\begin{array}{l}80,54 \\
\%\end{array}$ \\
\hline
\end{tabular}


Fedro et al., International Journal of Advanced Trends in Computer Science and Engineering, 10(5), September - October 2021 , 3046 - 3052

\begin{tabular}{|c|l|l|}
\hline 4 & Control & $\begin{array}{l}84,57 \\
\%\end{array}$ \\
\hline 5 & Joy & $\begin{array}{l}85,02 \\
\%\end{array}$ \\
\hline 6 & Behavioral intention to use & $\begin{array}{l}82,47 \\
\%\end{array}$ \\
\hline 7 & Immersion & $\begin{array}{l}79,56 \\
\%\end{array}$ \\
\hline
\end{tabular}

Based on the percentage results that shown in Table 9, the average percentage of all aspects $(83.99+83.76+80.54+$ $84.57+85.02+82.47+79.56) / 7$ is $82.84 \%$. The aspect with the highest average percentage is joy with a percentage of $85.02 \%$. And for the lowest average percentage is immersion with a percentage of $79.56 \%$.

\section{CONCLUSION}

Based on the research that has been done, some conclusions are obtained as follows.

1. The mandarin learning application with the android based gamification method has been successfully designed and built.

2. The application has been evaluated by 35 respondents using the Hedonic Motivation System Model (HMSAM). And get the results that respondents strongly agree to use this application again in the future, this is indicated by the percentage value on the aspect of reuse (Behavioral Intention to Use) of $82,47 \%$. and agree that user get carried away when using this application, this is indicated by the percentage value in the immersion aspect of $79,56 \%$.

Based on the research that has been done, there are several suggestions that can be used for advanced development, among others as follows.

1. Add a feature for writing hanzi, which is useful for improving the user ability in mandarin.

2. Adding other elements to the social drive influence \& relatedness, unpredictability \& curiosity, and loss \& avoidance. Such as friending elements, easter eggs, status quo sloths, and others. In order to further improve the playing experience, interest, and motivation of users in using the application.

Develop applications to run on the IOS platform, so that they can reach more users.

\section{ACKNOWLEDGEMENT}

Thank you to the Universitas Multimedia Nusantara, Indonesia which has become a place for researchers to develop this journal research. Hopefully, this research can make a major contribution to the advancement of technology in Indonesia.

\section{REFERENCES}

1. Alvinia Glori Handoyo, Zaim Elmubarok, and Titin Komala Sari, "Journal of Chinese Learning and Teaching," Journal of Chinese Learning and Teaching, vol. 1, no. 2, pp. 47-51, 2018.

2. Y. Ying, M. N. Suprayogi, and E. A. Hurriyati, "MOTIVASI BELAJAR BAHASA MANDARIN SEBAGAI BAHASA KEDUA," Humaniora Journal, vol. 4, no. 2, pp. 1345-1355, 2013.

3. R. A. Syakuran and Sufa'atin, "PEMBELAJARAN MATEMATIKA BERBASIS ANDROID Teknik Informatika - Universitas Komputer Indonesia," Elibrary.unikom, 2017.

4. S. C. Santo and N. M. S. Iswari, "Design and Development of Animal Recognition Application Using Gamification and Sattolo Shuffle Algorithm on Android Platform," International Journal of New Media Technology, vol. 4, no. 1, pp. 46-53, 2017.

5. J. F. Figueroa Flores, "Using Gamification to enhance second language learning," Digital Education Review, no. 27, pp. 32-54, 2015.

6. H. Jusuf, "Penggunaan Gamifikasi dalam Proses Pembelajaran," Jurnal TICOM, vol. 5, no. 1, pp. 1-6, 2016.

7. E. F. Rahmani, "The Benefits of Gamification in the English Learning Context," IJEE (Indonesian Journal of English Education), vol. 7, no. 1, pp. 32-47, 2020.

8. D. Rawendy, Y. Ying, Y. Arifin, and K. Rosalin, "Design and Development Game Chinese Language Learning with Gamification and Using Mnemonic Method," Procedia Computer Science, vol. 116, pp. 61-67, 2017.

9. N. B. S. Wangi, "Strategi Gamifikasi Pada Mata Kuliah Kewirausahaan Prodi PGMI Unisda," MIDA : Jurnal Pendidikan Dasar Islam, vol. 2, no. 2, pp. 9-20, 2019.

10. R. M. Andrias and M. S. Sunar, "User/player type in gamification," International Journal of Advanced Trends in Computer Science and Engineering, vol. 8, no. 1.6 Special Issue, pp. 89-94, 2019.

11. M. Takdir, "Kepomath Go "Penerapan Konsep Gamifikasi Dalam Pembelajaran Matematika Dalam Meningkatkan Motivasi Belajar Matematika Siswa ,", Penelitian Pendidikan INSANI, vol. 20, pp. 1-6, 2017.

12. D. L. Fay, S. Akhavan, and V. M. Goldberg, "PENGEMBANGAN BAHAN AJAR GAMIFIKASI PADA MATERI BANGUN RUANG SISI LENGKUNG SISWA SMP," Angewandte Chemie International Edition, 6(11), 951-952., no. 465, pp. 106-111, 1967.

13. L. Christopher and A. Waworuntu, "Java Programming Language Learning Application Based on Octalysis Gamification Framework," IJNMT (International Journal of New Media Technology), vol. 8, no. 1, pp. 65-69, 2021.

14. P. B. Lowry, J. E. Gaskin, N. W. Twyman, B. Hammer, and T. L. Roberts, 'Taking 'fun and games' seriously: Proposing the hedonic-motivation system adoption 
model (HMSAM)," Journal of the Association for Information Systems, vol. 14, no. 11, pp. 617-671, 2013.

15. Darmanto, Y. Hari, and B. Hermawan, "Rancang Bangun Media Pembelajaran Bahasa Mandarin Berbasis Mobile Learning," Jurnal Nasional Pendidikan Teknik Informatika (JANAPATI), vol. 4, no. 1, p. 1, 2015.

16. O. D. Apuke, "Quantitative Research Methods: A Synopsis Approach," Kuwait Chapter of Arabian Journal of Business and Management Review, vol. 6, no. 11, pp. 40-47, 2017. 